(c) American Dairy Science Association, 2003.

\title{
Milk Yield and Mammary Growth Effects Due to Increased Milking Frequency During Early Lactation
}

\author{
S. A. Hale, ${ }^{\star}$ A. V. Capuco, $†$ and R. A. Erdman* \\ *Department of Animal Science, \\ University of Maryland, College Park 20742 \\ †Gene Evaluation and Mapping Laboratory, \\ ANRI, USDA-ARS, Beltsville, MD 20705
}

\begin{abstract}
Increased milking frequency (IMF) at the beginning of lactation has been shown to increase milk yield not only during IMF but also after its cessation. The objectives of this experiment evaluated the effects of increased milking frequency initiated during early lactation on mammary growth and effects on milk yield (MY). Thirty-one cows were divided into treatment groups: 1) 2X: cows milked twice daily (2X) beginning at parturition (d 1), 2) IMF1: cows milked four times daily (4X) from d 1 to 21 postpartum (PP) and 3) IMF4: cows milked $2 \mathrm{X} \mathrm{d} 1$ to 3 and $4 \mathrm{X} \mathrm{d} 4$ to $21 \mathrm{PP}$. The $4 \mathrm{X}$ cows were milked immediately before $2 \mathrm{X}$ cows and again approximately $3 \mathrm{~h}$ later, at the end of the normal milking routine. All cows were milked $2 \mathrm{X}$ from $\mathrm{d} 21$ to 305 postpartum. Milk yields were 34.5, 37.8 and 37.6 $\mathrm{kg} / \mathrm{d}$ during wk 1 to 44 for $2 \mathrm{X}$, IMF1 and IMF4, respectively. Mammary biopsies from four cows per treatment were obtained on $\mathrm{d} 7$ and $14 \mathrm{PP}$ to evaluate mammary cell proliferation. Tritiated-thymidine incorporation tended to increase on $\mathrm{d} 7 \mathrm{in}$ IMF1 cows, and arithmetic means of the percentage of cells expressing Ki-67 proliferation antigen were consistent with a proliferative response to IMF though not significant. Blood was sampled three times per wk during the first 2 wk and then once per wk during wk $3,4,5,6,8$, and 10. Plasma insulin-like growth factor-1 (IGF-1) averaged $20.1 \mathrm{ng} /$ $\mathrm{ml}$ in IMF cows vs. 24.2 in $2 \mathrm{X}$ but was not accompanied by a change in bST. Prolactin was also not affected by treatment. Neither milk yield nor potential effects on mammary cell proliferation were correlated with systemic IGF-1. Implementing an IMF routine increases MY during treatment and elicits a carryover effect on the remainder of lactation. Milk yield responses after an IMF routine may be the result of increased mammary cell proliferation.
\end{abstract}

Received September 7, 2002.

Accepted December 6, 2002.

Corresponding author: R. A. Erdman; e-mail: re13@umail. umd.edu.
(Key words: milking frequency, milk yield, mammary growth)

Abbreviation key: FIL = feedback inhibitor of lactation, IMF = increased milking frequency, $\mathbf{M U N}=$ milk urea nitrogen, $\mathbf{M F}=$ milking frequency, $\mathbf{M Y}=$ milk yield, $\mathbf{P P}=$ postpartum, $\mathbf{P R L}=$ prolactin, $\mathbf{T U N E L}=$ terminal deoxynucleotidyl transferase dUTP nick end labeling, $\mathbf{X}=$ times daily.

\section{INTRODUCTION}

Milk yield (MY) in dairy cows can be increased by a variety of means including improvements in genetics, environment, hormone treatment and other factors. One of the most fundamental methods to increase MY is by increasing milking frequency (IMF). In most experiments where the effects of IMF on milk production have been measured, IMF was initiated at the beginning and continued for the entire lactation period (Lush and Shrode, 1950; DePeters et al., 1985). A few experiments (Pearson et al., 1979; Poole, 1982; Bar Peled et al., 1995) have evaluated the effects of targeted periods of IMF during specific stage of lactation. Studies where IMF occurred only during early lactation demonstrated increased milk yields, even after the IMF ended, thereby exhibiting a carry-over effect of early lactation IMF on MY during later lactation (Bar-Peled et al., 1995; Sanders, 2000). Although it has been shown that IMF during early lactation does increase MY, timing of IMF initiation, the duration of IMF to obtain a significant carry-over effect, and the cellular and hormonal mechanisms of carry-over effects remain to be investigated.

Experiments using both goats and cattle show that maintenance of peak milk yield and increases in persistency are heavily reliant upon the cellular dynamics of the mammary gland; specifically, the rates of cell proliferation, cell differentiation, apoptosis and the secretory capacity per cell (Tucker, 1981; Wilde et al., 1987; Hillerton et al., 1990). A strong relationship exists between numbers of mammary cells and milk yield (Tucker, 1966; Capuco et al., 2001). During lactation, 
maintenance of cell number by increasing cell proliferation or decreasing the rate of apoptosis should help maintain milk production. Increasing milking frequency at the beginning of lactation may provide a mechanism for increasing mammary cell numbers therefore increasing lactational MY and providing an explanation for the carryover effect of early lactation IMF on subsequent MY. In goats, IMF treatment corresponds with an increase in mammary cell numbers (Wilde et al., 1987). On the contrary, in cattle, administration of bST during mid or late lactation does not significantly affect mammary cell numbers (Capuco et al., 2001). However, the relationship between IMF during early lactation and mammary cells has not been evaluated in cows.

Finally, in previous studies by Bar Peled et al. (1995) and Sanders et al. (2000) implemented early lactation IMF was initiated on d $1 \mathrm{PP}$ and continued for up to 6 wk. However, since the first few milkings after parturition (up to $72 \mathrm{~h}$ ) are usually discarded because of antibiotic residues from dry cow therapy, it is of practical importance to determine if the timing of IMF treatment is critical. Specifically, could early lactation IMF be delayed until d $4 \mathrm{PP}$ and still result in the same carryover effects on MY as compared to initiation on $d$ $1 \mathrm{PP}$ ?

The objectives of the present investigation were: 1 ) to determine the effects of early lactation IMF on MY during the early lactation IMF period; 2) to determine the timing at which when IMF treatment must begin in order to stimulate carryover effects on lactation MY; and 3) to investigate potential cellular and hormonal mechanisms responsible for carry-over effects of IMF on lactation MY.

\section{MATERIALS AND METHODS}

\section{Cows and Treatments}

Thirty-one multiparous Holstein cows calving in the Beltsville Agricultural Research Center dairy herd were used in the study, which began just after parturition. Cows were housed in tie stalls during the $3 \mathrm{wk}$ treatment period and in a free-stall barn for the remainder of lactation. Cows were fed a TMR to provide $100 \%$ of NRC requirements daily at 1100 (Table 1). Use of animals for these investigations was approved by the Beltsville Agricultural Research Center's Animal Care and Use Committee.

Cows were blocked in groups of three based on calving date and randomly assigned to one of three treatment groups within each block. Milking frequency treatments consisted of: 1) 2X: cows milked twice daily (2X) beginning at parturition (d 1), 2) IMF1: cows milked four times daily (4X) from d 1 to 21 postpartum (PP) and 3) IMF4: cows milked $2 \mathrm{X}$ from $\mathrm{d} 1$ to 3 and $4 \mathrm{X} \mathrm{d} 4$ to $21 \mathrm{PP}$. All cows were milked twice daily from d 22 through d $305 \mathrm{PP}$. The increased milking frequency in the IMF1 and IMF4 treatments was accomplished as follows: At the beginning of the normal $2 \mathrm{X}$ milking times for the Beltsville Agricultural Research Center's dairy herd, which occurred at 0630 and 1730 h, IMF1 and IMF4 cows were milked first. After milking the remaining herd, IMF1, and IMF4 cows, were milked again ( 2 to $3 \mathrm{~h}$ later) to provide four milkings per day during the appropriate period of increased milking frequency. Thus, in the IMF groups, the approximate milking intervals were $9,3,9$ and $3 \mathrm{~h}$, respectively.

\section{Mammary Biopsies}

Mammary biopsies were obtained approximately $( \pm 2$ d) on d 7 and d 14 of treatment from four cows randomly assigned per treatment group to be biopsied. Biopsies (approximately 1-g wet tissue weight) were obtained on $\mathrm{d} 7$ from the left rear quarter and on $\mathrm{d} 14$ from the right rear quarter from the same 4 cows in each treatment group by the method of Farr et al. (1996). Mammary tissue was used to measure rates of cell proliferation as measured using ${ }^{3} \mathrm{H}$-thymidine incorporation and Ki-67 nuclear proliferation antigen localization and rates of apoptosis using terminal deoxynucleotidyl transferase nick end labeling (TUNEL). Tissues were placed in Medium 199 (Gibco BRL, Grand Island, NY) and transported to the laboratory for incubation with ${ }^{3} \mathrm{H}$-thymidine. Mammary tissues for immunohistochemistry were fixed in $10 \%$ neutral buffered formalin overnight at $4{ }^{\circ} \mathrm{C}$ and transferred to $70 \%$ ethanol until further processing. Tissues were then dehydrated and embedded in paraffin according to standard techniques and sectioned at $6-\mu \mathrm{m}$ onto salinated slides.

\section{Immunohistochemistry}

Ki-67 localization. Immunohistochemical localization of Ki-67 cell proliferation antigen was performed as described by Capuco et al. (2001). Briefly, slides were deparaffinized in xylene and hydrated in a graded series of ethanol. Tissue sections were quenched with $3 \% \mathrm{H}_{2} \mathrm{O}_{2}$ in PBS for $10 \mathrm{~min}$ and then washed in PBS $(3 \times 2 \mathrm{~min})$. Slides were microwaved at high power $(650 \mathrm{~W})$ in 400 $\mathrm{ml}$ of $10 \mathrm{~m} M$ citrate buffer ( $\mathrm{pH}$ 6.0) in a covered glass staining dish for $5 \mathrm{~min}$, remained undisturbed for 5 min, and then were microwaved for an additional 5 min. Slides remained in the buffer for a 30-min cooling period. They were then washed in PBS $(3 \times 2 \mathrm{~min})$ and blocked with $5 \%$ non-immune goat serum in PBS (30 $\mathrm{min}$ ) prior to histochemical localization of $\mathrm{Ki}-67$ antigen. Staining Ki-67 utilized the MIB-1 monoclonal anti- 
Table 1. Ingredient (\% DM basis) and estimated nutrient composition of diets fed during the lactation experiments.

\begin{tabular}{|c|c|c|c|}
\hline Ingredient & $\begin{array}{l}1-12-01 \text { to } \\
04-06-01\end{array}$ & $\begin{array}{l}04-06-01 \text { to } \\
08-21-01\end{array}$ & $\begin{array}{l}08-21-01 \text { to } \\
\text { end }\end{array}$ \\
\hline Concentrate mix & 47.0 & 42.2 & 43.75 \\
\hline Corn silage & 25.8 & 27.8 & 19.26 \\
\hline Alfalfa silage & 14.3 & 10.88 & 7.71 \\
\hline Orchard grass silage & 5.6 & 5.5 & \\
\hline Whole cottonseed & 3.7 & 3.68 & 5.2 \\
\hline Alfalfa hay & 3.6 & 3.6 & 7.71 \\
\hline Soybean hulls & $\ldots$ & 1.82 & \\
\hline Citrus pulp & $\ldots$ & 4.50 & 5.2 \\
\hline Orchard grass hay & $\ldots$ & $\ldots$ & 3.85 \\
\hline Wheat straw & $\ldots$ & $\ldots$ & 3.85 \\
\hline Roasted soybeans & $\ldots$ & $\ldots$ & 3.47 \\
\hline \multicolumn{4}{|c|}{ Estimated Chemical Composition (\% DM basis) } \\
\hline Net energy for lactation, Mcal $/ \mathrm{kg}$ & 1.67 & 1.69 & 1.80 \\
\hline Crude protein, $\%$ & 17.4 & 17.8 & 17.8 \\
\hline RUP, $\%$ & 7.2 & 6.69 & 7.23 \\
\hline Fat, $\%$ & 5.4 & 6.0 & 5.1 \\
\hline NDF, $\%$ & 31.1 & 30.6 & 28.4 \\
\hline Calcium, $\%$ & 0.90 & 0.9 & 0.78 \\
\hline Phosphorus, \% & 0.45 & 0.39 & 0.57 \\
\hline Magnesium,\% & 0.32 & 0.33 & 0.38 \\
\hline Potassium,\% & 1.52 & 1.54 & 1.52 \\
\hline Sulfur, $\%$ & 0.25 & 0.25 & 0.24 \\
\hline Sodium, $\%$ & 0.42 & 0.41 & 0.34 \\
\hline Chloride, $\%$ & 0.36 & 0.35 & 0.44 \\
\hline Iron, $\%$ & 159 & 162 & 201 \\
\hline Zinc, $\%$ & 100 & 89 & 76 \\
\hline Manganese,\% & 81 & 64 & 60 \\
\hline Copper,\% & 30 & 26 & 28 \\
\hline Selenium, $\%$ & 0.31 & 0.29 & 0.45 \\
\hline Vitamin A, IU/kg & 7546 & 7304 & 8154 \\
\hline Vitamin D, IU/kg & 1892 & 1826 & 2039 \\
\hline Vitamin E, IU/kg & 31.7 & 24.6 & 27.2 \\
\hline
\end{tabular}

body (prediluted MIB-1, Zymed Laboratories, San Francisco, CA) and Histostain SP kit (Zymed). The slides were incubated with primary antibody for $60 \mathrm{~min}$ at room temperature and then washed with PBS $(3 \times$ $5 \mathrm{~min}$ ). Slides were then incubated for $10 \mathrm{~min}$ at room temperature with biotinylated secondary antibody and washed in PBS $(3 \times 2 \mathrm{~min})$. Slides were then incubated with streptavidin-peroxidase-conjugate for $10 \mathrm{~min}$ at room temperature. After washing in PBS $(3 \times 5 \mathrm{~min})$, sections were incubated with diaminobenzidine. Slides were washed with distilled $\mathrm{H}_{2} \mathrm{O}$, counterstained with hematoxylin, dehydrated, and then mounted with Permaslip.

Terminal deoxynucleotidyl transferase dUTP nick end labeling. As described by Capuco et al. (2001), in situ detection of apoptotic cells utilized TUNEL to visualize cells that exhibited endonucleotidyl degradation of DNA, a key feature of apoptotic cells. A commercial kit (Apoptag kit, Oncor, Gaithersburg, MD) was used. After deparaffinization and hydration, slides were incubated with proteinase $\mathrm{K}(20 \mu \mathrm{g} / \mathrm{ml}$ of PBS, Oncor). Tissue sections were quenched with $2 \% \mathrm{H}_{2} \mathrm{O}_{2}$ in PBS for $10 \mathrm{~min}$ and then washed in PBS $(2 \times 5 \mathrm{~min})$.
Slides were incubated in equilibration buffer for $10 \mathrm{~min}$ and then incubated with terminal deoxynucleotidyl transferase for $60 \mathrm{~min}$ in a humidified chamber at room temperature. Tissue sections were washed with stop/ wash buffer for $10 \mathrm{~min}$ at room temperature and then incubated with anti-digoxigenin-peroxidase for $30 \mathrm{~min}$ at room temperature in a humidified chamber. Tissue sections were washed in PBS $(4 \times 2 \mathrm{~min})$ and then incubated with diaminobenzidine until development of color, approximately $4 \mathrm{~min}$. Sections were washed with distilled $\mathrm{H}_{2} \mathrm{O}$ and then counterstained with $0.1 \%$ methyl green in acetate buffer, $\mathrm{pH} 4$, washed in three changes of distilled $\mathrm{H}_{2} \mathrm{O}$, dehydrated in butanol and xylene and then mounted with Permaslip.

Quantitation of immunohistochemistry. Tissue sections were viewed by light microscopy to quantify Ki-67 antigen expressing cells, and apoptotic cells. For each tissue section, five microscopic fields were quantified. A field was selected under low power and slightly out of focus, then the objective was switched to higher power, a digital image of the microscope field was taken at $100 \times$ magnification and cells were counted on a computer monitor. 


\section{${ }^{3} \mathrm{H}$-thymidine Incorporation}

Mammary tissue from cows was sliced with a StadieRiggs hand microtome (Arthur H. Thomas Co., Philadelphia, PA). Triplicate slices (approximately $60 \mathrm{mg}$ ) were each incubated in $3 \mathrm{ml}$ of Medium 199 containing $1 \mu \mathrm{Ci}$ of ${ }^{3} \mathrm{H}$-thymidine/ml (Amersham Biosciences, Piscataway, $\mathrm{NJ}$ ). Incubation was for $2 \mathrm{~h}$ at $37^{\circ} \mathrm{C}$ in a shaking water bath, under an atmosphere of $5 \% \mathrm{CO}_{2}$ and 95\% $\mathrm{O}_{2}$. After incubation, tissues were rinsed in $0.9 \%$ saline and frozen at $-20^{\circ} \mathrm{C}$ until quantification of incorporation. Tissue slices were homogenized in saline, precipitated with trichloroacetic acid and radioactivity determined by liquid scintillation spectroscopy, as described previously (Capuco and Akers, 1990).

\section{DNA Analyses}

To quantify nucleic acids, mammary tissue was homogenized (1:15 wt/vol) in DNA assay buffer $(50 \mathrm{mM}$ $\mathrm{Na}_{2} \mathrm{PO}_{4}, 2 M \mathrm{NaCl}, 2 \mathrm{mM} \mathrm{Na}{ }_{2}$ EDTA) using a Tekmar Homogenizer (Tekmar, Cincinnati, OH). DNA was quantified using Hoechst 33258 dye binding (Labarca and Paigen, 1980). Five-micrometer aliquots of sample homogenates were transferred to a 96 -well microplate. Then $195 \mu \mathrm{l}$ of DNA assay buffer containing Hoechst dye $[99.8 \mathrm{ml}$ of DNA assay buffer $+200 \mu$ l dye solution (1 $\mu \mathrm{g}$ of Hoechst $33258 \mathrm{dye} / \mu \mathrm{l}$ distilled water)] was added to each sample. A standard curve containing 0 to $2 \mu \mathrm{g}$ of calf thymus DNA per well was prepared. Fluorescence was read using a Bio-Tek FL600 plate reader with a 360/460 $\mathrm{nm}$ filter set (Bio-Tek Instruments, Inc., Winooski, VT).

\section{Measurements}

Milk production was electronically recorded at each milking for the 305-d lactation period. Milk samples were collected weekly from two consecutive milkings and analyzed for fat, protein, solids, lactose, and SCC using an infrared analyzer (Bentley Instruments, St. Paul, MN) and milk urea nitrogen (MUN; Bentley Chemspec, Chaska, MN) by Lancaster DHIA (Manheim, PA) for the first 10 wk PP.

Cow body weight and body condition scores were recorded on the same day weekly for the first $10 \mathrm{wk}$ PP. Body condition scores were based on a 5-point scale (Edmonson et al., 1989) and were assessed by a single individual (S. A. Hale).

\section{Blood Sampling and Analysis}

Blood was sampled at $1300 \mathrm{~h}$ three times per week during the first $2 \mathrm{wk}$ and then once per week during wk $3,4,5,6,8$, and 10 . Blood was collected by tail venipuncture with $9 \mathrm{ml} \mathrm{K}$ EDTA Vacutainer tubes and 20-gauge needles (Becton Dickinson Vacutainer Systems, Rutherford, NJ). Samples were centrifuged at $2000 \times g$ for $30 \mathrm{~min}$, and plasma was decanted and stored at $-20^{\circ} \mathrm{C}$ until concentrations of prolactin (PRL), bST and IGF-1 were determined using previously validated radioimmunoassays (Elsasser et al., 1989; Miller et al., 1999). Bovine PRL AFP-4835B; anti-bPRL AFP753180Rb; anti-hIGF-1 AFP-4892898; were provided by Dr. Parlow, NHPP, and NIDDK, Torrance, CA. Bovine somatotropin (USDA-bST-b1) was provided by the USDA Animal Hormone Program (Dr. Proudman, Building 200, BARC-East, Beltsville, MD). Rabbit-antibovine somatotropin (R1-1-3) was kindly donated by Dr. Elsasser (USDA-ARS Bldg. 200, BARC-East, Beltsville, MD). Intraassay and interassay coefficients of variation averaged, respectively, 12 and 9\% for IGF-1 (two assays). Intraassay coefficients of variation were $5 \%$ for PRL (one assay) and 9\% for bST (one assay).

\section{Statistical Analyses}

Milk production data and milk component data was analyzed using ANOVA with repeated measures using the Mixed Procedure in SAS (version 8; SAS Institute, Inc., Cary, NC). The statistical model included: Covariant, Block, Treatment, Cow (treatment), day PP, and day PP by treatment interaction. Previous 305-d adjusted milk production was used as a covariate in the ANOVA and milk production data is reported as covariance adjusted least squares means. This model was tested separately between treatment groups for the wk 1 to 3 , wk 4 to 10 , wk 4 until 305-d and the complete lactation. Mammary tissue parameters and blood hormonal data were analyzed by ANOVA with repeated measures using the Mixed Procedure in SAS. The statistical model included: Block, Treatment, Cow (treatment), day postpartum, and day postpartum $\times$ treatment interaction.

\section{RESULTS}

Milk production responses are shown in Figure 1 and Table 2. During wk 1 to 3 daily, milk yield in the IMF1 and IMF4 groups were 8.8 and $4.8 \mathrm{~kg}$ higher than the $2 \mathrm{X}$ cows. Although statistically not different, milk production in the IMF1 group was consistently greater than that in the IMF4 group during the treatment period (Figure 1). In proportion to the short milking interval, milk production for the second $4 \mathrm{X}$ morning and evening milkings averaged $6.0 \mathrm{~kg}(\mathrm{SE} \pm 0.28)$ and 4.9 $\mathrm{kg}(\mathrm{SE} \pm 0.24)$, respectively across the IMF groups. Peak milk production occurred during wk 7 for the $2 \mathrm{X}$ cows, and during wk 8 for IMF1 and IMF4 cows (Figure 1). 


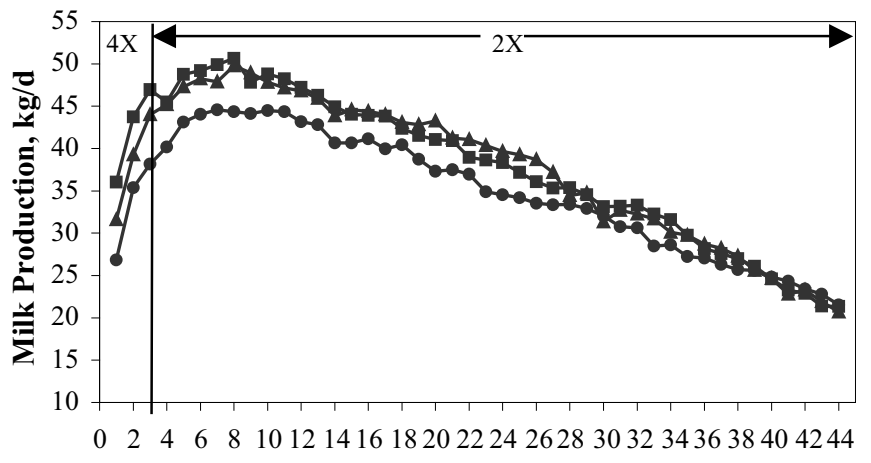

Week in Lactation

Figure 1. Milk production of cows milked $2 \mathrm{X}(\bullet), 4 \mathrm{X}$ starting at d 1 postpartum $(\mathrm{PP})$ until d $21 \mathrm{PP}(\boldsymbol{\Delta}$; IMF1) and $4 \mathrm{X}$ starting at d 4 PP until d 21 PP (匹; IMF4) for the complete 305-d lactation. SEM $\pm 1.91 \mathrm{~kg} / \mathrm{d}$.

Milk production was greater in the $4 \mathrm{X}$ groups than the $2 \mathrm{X}$ group during the majority of lactation until all groups converged during late lactation $(P<0.05)$ demonstrating a carryover effect of IMF treatment.

During wk 4, milk production decreased slightly (1.5 $\mathrm{kg} / \mathrm{d}$ ) in the IMF1 group, while there was no analogous decrease in the IMF4 group. Despite immediate posttreatment decreases in the IMF1 group, milk production rebounded by $3.6 \mathrm{~kg} / \mathrm{d}$ during wk 5 and continued to increase until peak during wk 8 PP. After peak milk at wk 8 , production for IMF1 and IMF4 groups remained higher than that for $2 \mathrm{X}$ cows at 39.2, 39.5 and $36.5 \mathrm{~kg} / \mathrm{d}$, respectively. Groups converged at wk 36 (Figure 1) and were similar for the remainder of lactation. For the complete lactation, milk production for the IMF1 and IMF4 groups were similar and $3.0 \mathrm{~kg} / \mathrm{d}$ greater than for $2 \mathrm{X}$ group $(P<0.05)$.

Concentrations of milk components are shown in Table 2. During the $3 \mathrm{wk}$ treatment period, there was decreased fat percentage between the $4 \mathrm{X}$ and $2 \mathrm{X}$ groups $(P<0.05)$. After treatment, the $2 \mathrm{X}$ group maintained the higher fat percentage $(P<0.05)$. The IMF1 group had higher fat percentage from wk 4 to 44 as compared to IMF4 $(P<0.05)$ (Table 2$)$. The $4 \mathrm{X}$ groups had tended to have lower milk protein percentage during wk 4 to $44(P<0.10)$. Increased milking frequency also tended to decrease the lactose percentage during the treatment period and the posttreatment period, wk 4 to $10(P<$ 0.10 ). There were no treatment effects on milk urea nitrogen. Milk SCC was low for all the treatments and did not differ between the $4 \mathrm{X}$ and $2 \mathrm{X}$ groups $(P<0.05)$. During wk 4 to 10 , milk SCC was significantly lower in the IMF4 group as compared to the IMF1 group ( $P$ $<0.05)$.

Fat corrected milk (3.5\%) and milk component yields during the first $10 \mathrm{wk}$ PP and monthly thereafter are shown in Table 3. There were no differences due to IMF

Table 2. Least squares means for milk yield and concentrations of milk components during wk 1 to 3,4 to 10 and 1 to 10 of lactation in cows milked $2 \mathrm{X}^{1}$ daily, $4 \mathrm{X}$ on d 1 postpartum (PP) until d $21 \mathrm{PP}$ (IMF $1^{1}$ ) and $4 \mathrm{X}$ on d 4 PP until d 21 PP (IMF4 $\left.{ }^{1}\right)$

\begin{tabular}{|c|c|c|c|c|c|c|c|}
\hline & \multirow[b]{2}{*}{ Wk PP } & \multicolumn{3}{|c|}{ Treatments } & \multirow[b]{2}{*}{ SEM } & \multicolumn{2}{|c|}{ Probability $^{2}$} \\
\hline & & $2 \mathrm{X}$ & IMF1 & IMF4 & & ${ }^{3} 2 \mathrm{X}$ vs. $4 \mathrm{X}$ & $\begin{array}{l}{ }^{4} \mathrm{IMF} 1 \\
\text { vs. IMF4 }\end{array}$ \\
\hline \multirow[t]{3}{*}{ Milk, kg/d ${ }^{5}$} & $1-3$ & 33.5 & 42.3 & 38.3 & 2.41 & 0.018 & 0.207 \\
\hline & $4-10$ & 43.8 & 48.4 & 47.7 & 3.20 & 0.012 & 0.659 \\
\hline & $4-44$ & 34.8 & 37.4 & 37.5 & 1.87 & 0.058 & 0.953 \\
\hline \multirow[t]{3}{*}{ Fat $\%^{5,6}$} & $1-3$ & 4.95 & 3.95 & 4.17 & 0.249 & 0.009 & 0.529 \\
\hline & $4-10$ & 4.08 & 3.88 & 3.54 & 0.161 & 0.069 & 0.121 \\
\hline & $4-44^{7}$ & 4.20 & 4.00 & 3.68 & 0.113 & 0.010 & 0.035 \\
\hline \multirow[t]{3}{*}{ Protein $\%$} & $1-3$ & 3.16 & 3.04 & 3.14 & 0.101 & 0.590 & 0.487 \\
\hline & $4-10$ & 2.62 & 2.50 & 2.52 & 0.160 & 0.016 & 0.674 \\
\hline & $4-44^{7}$ & 3.10 & 3.03 & 2.92 & 0.055 & 0.083 & 0.168 \\
\hline \multirow[t]{2}{*}{ Lactose $\%$} & $1-3$ & 4.87 & 4.77 & 4.61 & 0.084 & 0.089 & 0.144 \\
\hline & $4-10$ & 4.96 & 4.87 & 4.77 & 0.689 & 0.092 & 0.263 \\
\hline \multirow[t]{2}{*}{ MUN, mg/dl } & $1-3$ & 10.7 & 10.5 & 10.6 & 0.83 & 0.895 & 0.888 \\
\hline & $4-10$ & 10.7 & 10.4 & 11.3 & 0.52 & 0.794 & 0.212 \\
\hline \multirow{2}{*}{$\mathrm{SCC} 1000^{\prime} \mathrm{s} / \mathrm{ml}$} & $1-3$ & 37 & 46 & 73 & 12.6 & 0.284 & 0.316 \\
\hline & $4-10$ & 24 & 33 & 17 & 15.8 & 0.988 & 0.014 \\
\hline
\end{tabular}

${ }^{1}$ For $2 \mathrm{X}, \mathrm{n}=9$; for IMF1 and IMF4, $\mathrm{n}=11$.

${ }^{2}$ Probability that contrasts were not different.

${ }^{3}$ Contrast of $2 \mathrm{X}$ vs. IMF1 and IMF4 treatment groups.

${ }^{4}$ Contrast of IMF1 vs. IMF4 treatment groups.

${ }^{5}$ Covariate adjusted for previous lactation milk yield or component concentration.

${ }^{6}$ Milk samples were obtained at the first AM and PM milkings for 4X cows.

${ }^{7}$ Milk composition was analyzed weekly from wk 1 to 10 and monthly thereafter. 
Table 3. Least squares means for fat corrected milk (3.5\%) and milk component yields for cows milked $2 \mathrm{X}^{1}$, 4X from d 1 postpartum (PP) until d $21 \mathrm{PP}\left(\mathrm{IMF}^{1}{ }^{1}\right.$ ) and $4 \mathrm{X}$ from d 4 PP until d $21 \mathrm{PP}$ (IMF4 $4^{1}$ ).

\begin{tabular}{|c|c|c|c|c|c|c|c|}
\hline & \multirow[b]{2}{*}{ Wk PP } & \multicolumn{3}{|c|}{ Treatments } & \multirow[b]{2}{*}{ SEM } & \multicolumn{2}{|c|}{${ }^{2}$ Probability } \\
\hline & & $2 \mathrm{X}$ & IMF1 & IMF4 & & ${ }^{3} 2 \mathrm{X}$ vs. $4 \mathrm{X}$ & $\begin{array}{l}{ }^{4} \text { IMF1 } \\
\text { vs. IMF4 }\end{array}$ \\
\hline \multirow[t]{3}{*}{$3.5 \%$ FCM kg/d } & $1-3$ & 42.4 & 46.7 & 43.4 & 2.65 & 0.440 & 0.363 \\
\hline & $4-10$ & 47.8 & 51.3 & 47.8 & 1.26 & 0.433 & 0.149 \\
\hline & $4-44^{7}$ & 38.3 & 40.9 & 38.1 & 1.50 & 0.480 & 0.148 \\
\hline \multirow[t]{3}{*}{ Fat Yield, $g / d^{5,6}$} & $1-3$ & 1791 & 1645 & 1616 & 125.7 & 0.342 & 0.869 \\
\hline & $4-10$ & 1793 & 1898 & 1702 & 98.1 & 0.948 & 0.087 \\
\hline & $4-44^{7}$ & 1489 & 1484 & 1354 & 64.9 & 0.346 & 0.091 \\
\hline \multirow[t]{3}{*}{ Protein Yield, $\mathrm{g} / \mathrm{d}^{5,6}$} & $1-3$ & 1130 & 1283 & 1241 & 73.6 & 0.175 & 0.686 \\
\hline & $4-10$ & 1165 & 1216 & 1205 & 43.3 & 0.377 & 0.841 \\
\hline & $4-44^{7}$ & 1066 & 1105 & 1082 & 43.8 & 0.552 & 0.640 \\
\hline \multirow[t]{2}{*}{ Lactose Yield, g/d } & $1-3$ & 1730 & 2068 & 1854 & 102.6 & 0.092 & 0.138 \\
\hline & $4-10$ & 2186 & 2344 & 2276 & 83.6 & 0.231 & 0.533 \\
\hline
\end{tabular}

\footnotetext{
${ }^{1}$ For $2 \mathrm{X}, \mathrm{n}=9$; for IMF1 and IMF4, $\mathrm{n}=11$.

${ }^{2}$ Probability that contrasts were not different.

${ }^{3}$ Contrast of $2 \mathrm{X}$ vs. IMF1 and IMF4 treatment groups.

${ }^{4}$ Contrast of IMF1 vs. IMF4 treatment groups.

${ }^{5}$ Covariate adjusted for previous lactation milk yield or component yields.

${ }^{6}$ Milk samples were obtained at the first AM and PM milkings for $4 \mathrm{X}$ cows.

${ }^{7}$ Milk composition was analyzed weekly from wk $1-10$ and monthly thereafter.
}

treatment in FCM, or protein yield. After treatment, fat yield tended to be lower in the IMF4 group as compared to the IMF1 group $(P<0.10)$. Fat yield in the $2 \mathrm{X}$ group compared to the IMF groups did not differ $(P>$ $0.10)$. Lactose yield tended to be higher in the $4 \mathrm{X}$ groups as compared to the $2 \mathrm{X}$ groups during the treatment period $(P<0.01)$. Lactose yield did not differ between groups during wk 4 to 10 .

Average BW and BCS, measured during wk 1 to 10 $\mathrm{PP}$ are shown in Figure 2. Mean initial body weight (Figure 2; left panel) was greater in the IMF1 and IMF4 cows than the $2 \mathrm{X}$ cows $(P>0.05)$. Body weights of the IMF1 and IMF4 groups declined until wk 5. Body condition score declined by 0.1 to 0.2 units from wk 1 to 5

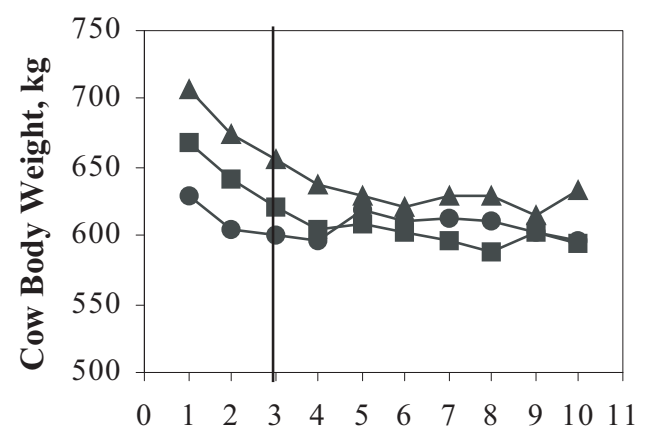

Week Postpartum
PP. There were no significant effects of IMF treatment on body condition (Figure 2; right panel; $P>0.05$ ).

Rates of mammary cell proliferation, as assessed by ${ }^{3} \mathrm{H}$-thymidine incorporation (Figure 3 ), were greater in the IMF1 group $(P<0.05)$ than in the $2 \mathrm{X}$ and IMF4 groups when measured on $\mathrm{d} 7 \mathrm{PP}$. On d 14, cell proliferation in the IMF1 group tended to be higher than $2 \mathrm{X}$ and IMF4 groups $(P<0.16$ and 0.06 , respectively). There were no other differences between groups or biopsy days.

Mammary cell proliferation rates were also assessed by the percentage of mammary cells expressing Ki-67 nuclear proliferation antigen (Figure 4). The percentage of mammary epithelial and stromal cells expressing



Week Postpartum

Figure 2. Left panel: Weekly BW (kg) during the first 10 wk of lactation in cows milked 2X (๑), 4X starting at d 1 postpartum (PP) until d 21 PP (ム; IMF1) and 4X starting at d 4 PP until d 21 (ם; IMF4). SEM $\pm 20.11 \mathrm{~kg}, P>0.05$. Right panel: Weekly BCS for cows






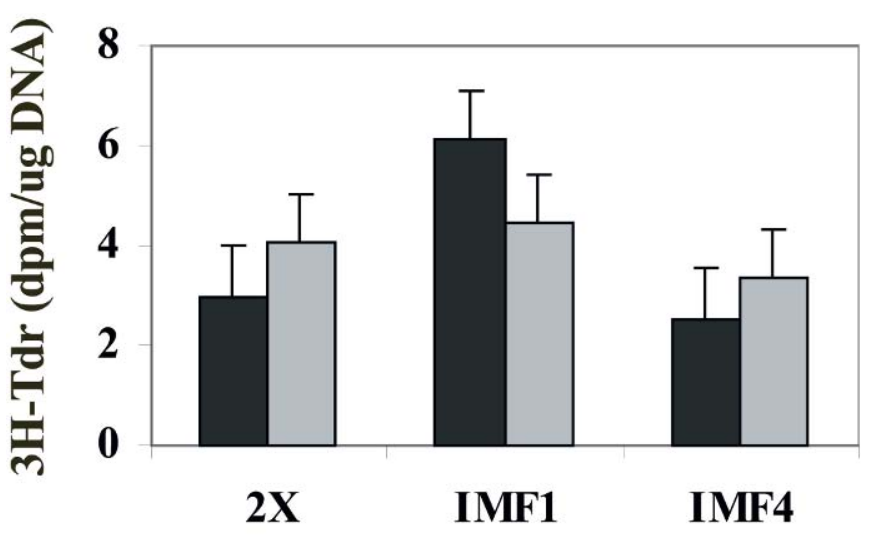

Treatments

Figure 3. Milking frequency effects on mammary cell proliferation on d 7 (solid bars) and d 14 (shaded bars) of lactation as measured by incorporation of ${ }^{3} \mathrm{H}$-thymidine during a 2-h incubation of mammary tissue slices. Cows were milked $2 \mathrm{X}, 4 \mathrm{X}$ starting at $\mathrm{d} 1$ postpartum (PP) until d $21 \mathrm{PP}$ (IMF1), 4X starting at d $4 \mathrm{PP}$ until d $21 \mathrm{PP}$ (IMF4). Each bar represents the mean $\pm \mathrm{SE}$ for 4 cows $(*=P<0.05)$.

Ki-67 in IMF and $2 \mathrm{X}$ cows did not differ due to treatment or biopsy day $(P>0.05)$. However, the epithelial labeling indices were numerically greatest for IMF1 on d 7 and IMF4 on d 14. Although not compared statistically, rates of stromal cell proliferation were approximately twice that of epithelial cell proliferation using Ki-67 (Figure 4).

Rates of mammary epithelial and stromal cell apoptosis are shown in Figure 5. There was a higher percentage apoptotic mammary epithelial cells on $\mathrm{d} 7$ in the IMF4 group (Fig. 5; left panel). The IMF4 d-7 apoptotic percentage was significantly higher than the $\mathrm{d} 7$ biopsy in the $2 \mathrm{X}$ group and the $\mathrm{d}-14$ biopsy in the IMF1 group $(P<0.05)$. Percentages of apoptotic mammary epithelial cells tended to be higher for IMF4 tissue on $\mathrm{d} 7$ than all other treatments and biopsy days $(P<0.10)$.

The apoptotic percentage of mammary stromal cells (Figure 5; right panel) was numerically greater $(P<$ 0.05) in the IMF1 treatment on $\mathrm{d} 7$ as compared to the $2 \mathrm{X}$ d-7 biopsy. On d 14, IMF4 stromal apoptosis was greater than $2 \mathrm{X}(P<0.05)$. Mammary stromal cells in IMF1 tissue tended to have a higher percentage of apoptotic cells on 7 than $14(P<0.10)$.

Concentrations of serum bST, IGF-1 and PRL by treatment and days PP are shown in Figures 6 through 8. Serum bST declined with time PP but was not affected by treatment $(P>0.05)$. Serum IGF-1 increased as lactation progressed and tended to be lower in the $\mathrm{IMF}$ groups than the $2 \mathrm{X}$ group, especially during the post treatment period (Figure 7). During the wk 1 to 3 , there were no effects of IMF treatment or day PP on serum PRL (Figure 8). During wk 4 to 10, serum PRL was not affected by treatment but was numerically higher in the IMF4 group as compared to the $2 \mathrm{X}$ and IMF1 group $(P>0.10)$.

\section{DISCUSSION}

Increasing milking frequency from $2 \mathrm{X}$ to $4 \mathrm{X}$ during the first $3 \mathrm{wk}$ PP increased MY by $8.8 \mathrm{~kg} / \mathrm{d}(26 \%)$ and 4.8
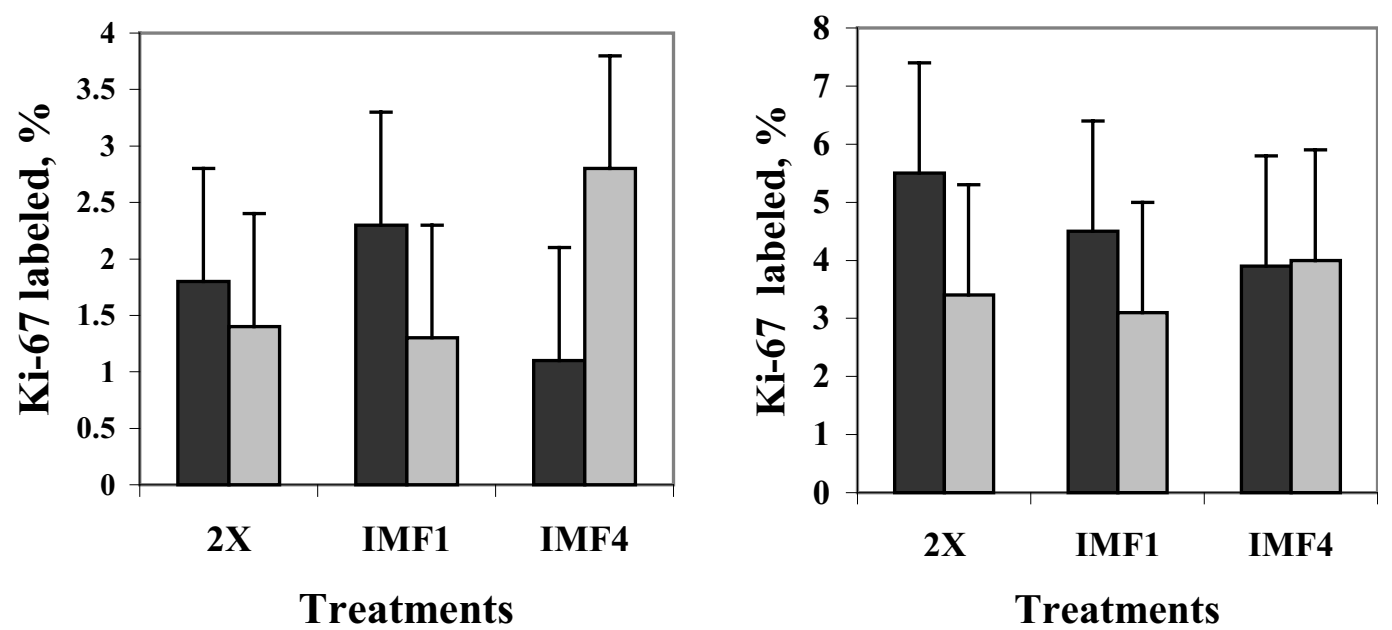

Figure 4. Effect of increased milking frequency on mammary cell proliferation on d 7 (solid bars) and d 14 (shaded bars) postpartum (PP) as evaluated by Ki-67 labeling index, expressed as a percentage of total cells. Cows were milked $2 \mathrm{X}, 4 \mathrm{X}$ starting at d 1 PP until d 21 PP (IMF1), 4X starting at d 4 PP until d 21 PP (IMF4). Each bar represents the mean \pm SE for 4 cows per treatment milking group. Left panel: epithelial labeling. Right panel: stromal labeling. Effect of milking on Ki-67 expression was nonsignificant $(P>0.05)$. 


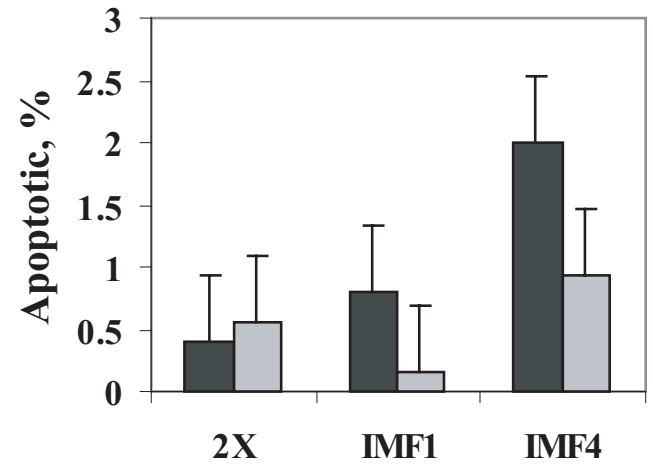

Treatments

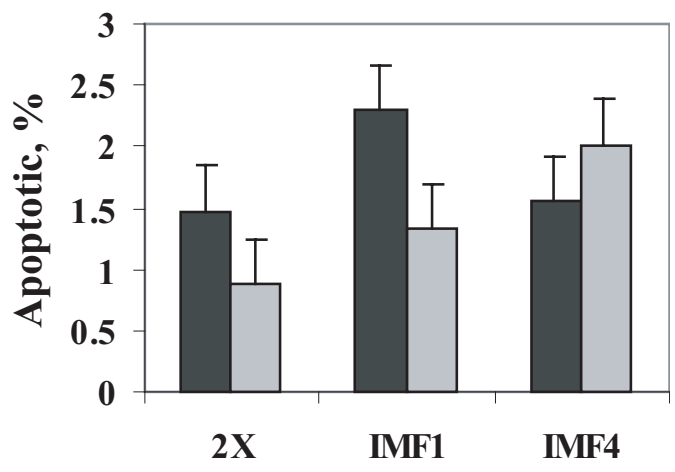

Treatments

Figure 5. Effect of increased milking frequency on d 7 (solid bars) and d 14 (shaded bars) of lactation on mammary cell apoptosis. Apoptotic index is expressed as percentage of total cells. Cows were milked 2X, 4X starting at d 1 postpartum (PP) until d 21 PP (IMF1), $4 \mathrm{X}$ starting at d 4 PP until d 21 PP (IMF4). Left panel: mammary epithelial cell apoptosis. Right panel: mammary stromal cell apoptosis. Each bar represents the mean \pm SE for 4 cows per increased milking frequency treatment group $(*=P<0.05)$.

$\mathrm{kg} / \mathrm{d}(14 \%)$ in the IMF1 and IMF4 groups, respectively. Similar differences were observed in other IMF studies where 6X milking was compared to 3X milking (Bar Peled et al., 1995; Sanders, 2000). Bar Peled et al. (1995) saw a $7.3 \mathrm{~kg} / \mathrm{d}(21 \%) \mathrm{MY}$ increase in $6 \mathrm{X}$ compared to $3 \mathrm{X}$ during a 6 -wk treatment period and Sanders (2000) saw increases in MY of $6 \mathrm{~kg} / \mathrm{d}(16 \%)$ in $6 \mathrm{X}$ compared to $3 \mathrm{X}$ mature cows.

Consistent with other early lactation IMF studies (Bar Peled et al., 1995; Sanders, 2000), MY remained higher in $4 \mathrm{X}$ cows than $2 \mathrm{X}$ cows after the treatment period. In previous studies (Bar Peled et al., 1995; Sanders, 2000), the treatment period was $6 \mathrm{wk}$ and IMF cows were milked $6 \mathrm{X}$ beginning $\mathrm{d} 1 \mathrm{PP}$. The current

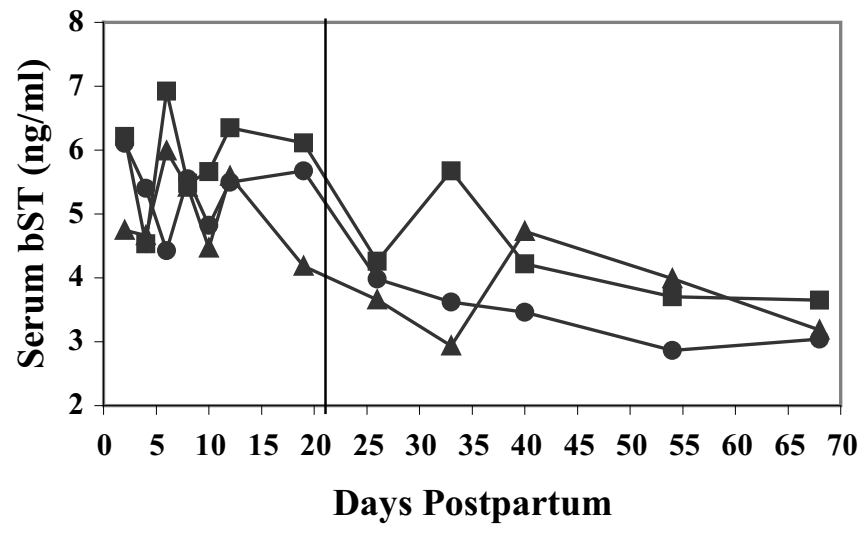

Figure 6. Serum bST concentrations $(\mathrm{ng} / \mathrm{ml})$ of cows milked $2 \mathrm{X}$ (๑), 4X beginning on d 1 postpartum (PP) until d 21 PP ( $\boldsymbol{\Delta}$; IMF1) and $4 \mathrm{X}$ beginning on d 4 PP until d 21 PP (ם; IMF4). Pooled SEM was $\pm 0.870 \mathrm{ng} / \mathrm{ml}$. The serum concentrations of GH were not different between $2 \mathrm{X}$ and IMF groups or IMF1 and IMF4 groups $(P>0.05)$. study employed a 3-wk treatment period during which IMF cows were milked $4 \mathrm{X}$ beginning $\mathrm{d} 1 \mathrm{PP}$ or d $4 \mathrm{PP}$ and daily milking intervals were not evenly distributed. Even with shorter and uneven milking intervals of approximately $9,3,9$, and $3 \mathrm{~h}$, MY responses were almost equal to IMF treatment where the milking interval was equally spaced throughout $24 \mathrm{~h}$ (Bar-Peled et al., 1995; Sanders, 2000).

Erdman and Varner (1995) reported a fixed yield increase of $3.5 \mathrm{~kg} / \mathrm{d}$ in cows milked $3 \mathrm{X}$ for an entire lactation. Other studies reported a $3.0 \mathrm{~kg} / \mathrm{d}$ (Pearson et al., 1979 ) and $4.0 \mathrm{~kg} / \mathrm{d}$ (Poole, 1982) increase of $3 \mathrm{X}$ over $2 \mathrm{X}$ milking during the $3 \mathrm{X}$ treatment period that continued until mid lactation with small and nonsignificant carryover effects. In these experiments (Pearson et al.,

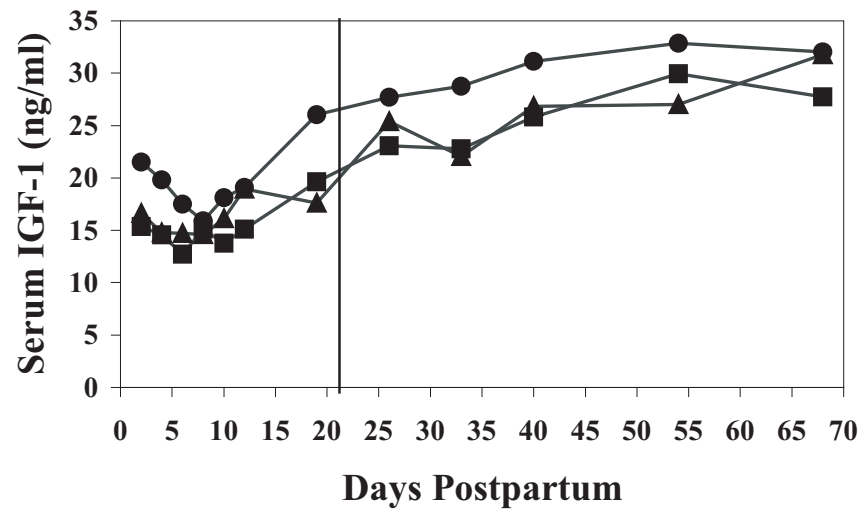

Figure 7. Serum insulin-like growth factor-1 (IGF-1) concentrations (ng/ml) of cows milked $2 \mathrm{X}(\bullet), 4 \mathrm{X}$ beginning on d 1 PP until d $21 \mathrm{PP}(\boldsymbol{\Lambda} ; \mathrm{IMF} 1)$ and $4 \mathrm{X}$ beginning on d 4 PP until d $21 \mathrm{PP}$ (ם; IMF4). Pooled SEM was $\pm 2.53 \mathrm{ng} / \mathrm{ml}$. The serum concentrations of IGF-1 were different between the $2 \mathrm{X}$ and IMF groups $(P<0.05)$. 


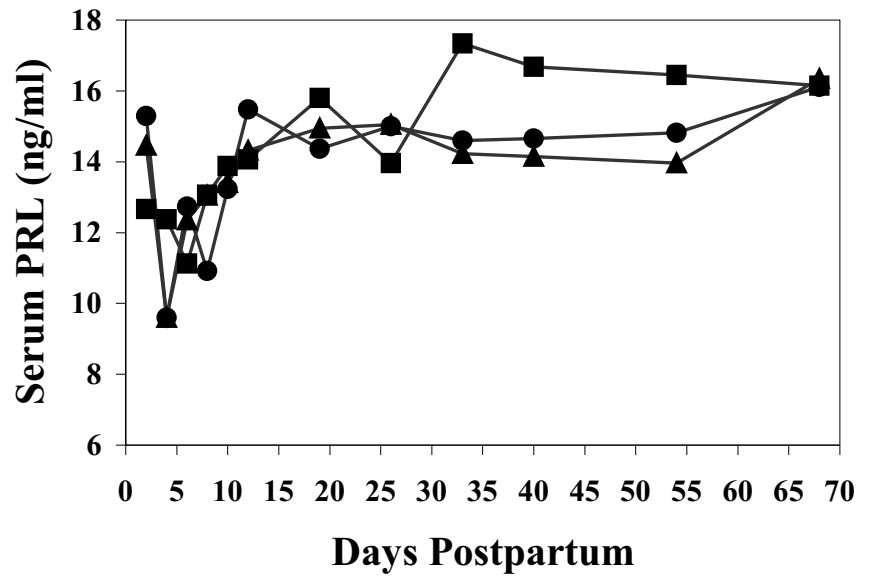

Figure 8. Serum prolactin (PRL) concentrations $(\mathrm{ng} / \mathrm{ml})$ of cows milked $2 \mathrm{X}(\bullet), 4 \mathrm{X}$ beginning on d 1 PP until d $21 \mathrm{PP}(\boldsymbol{\Lambda} ; \mathrm{IMF} 1)$ and $4 \mathrm{X}$ beginning on d 4 PP until d 21 PP ( $\mathbf{\square}$ IMF4). Pooled SEM was $\pm 1.20 \mathrm{ng} / \mathrm{ml}$. There was no difference between either the $2 \mathrm{X}$ and IMF groups or the IMF1 and IMF4 groups $(P>0.05)$.

1979; Poole 1982), carryover effects on MY were lower than in the current study where $4 \mathrm{X}$ cows continued to produce $2.8 \mathrm{~kg} / \mathrm{d}$ more than $2 \mathrm{X}$ cows until wk 36 when MY of all cows converged for the remainder of lactation. In contrast, Bar Peled et al. (1995) saw posttreatment (wk 7 to 18) increases in MY of $5.1 \mathrm{~kg} / \mathrm{d}$. In the present study, MY of $4 \mathrm{X}$ cows was $4.0 \mathrm{~kg} / \mathrm{d}$ higher than $2 \mathrm{X}$ cows for a $14 \mathrm{wk}$ period posttreatment. These data suggest that, there is a window during early lactation when IMF treatment may positively affect the mammary gland, resulting in increased MY even after IMF treatment has ceased.

IMF treatment generally alters the milk composition, specifically, fat and protein. Usually, as milking frequency increases, fat and protein decrease (Erdman and Varner, 1995). In the present study, there was a significant decrease in protein percentage during wk 4 to 10 , a decreased fat percentage $(P<0.05)$ during wk 1 to 3 and 4 to 44 , and a tendency for decreased lactose percentage during wk 1 to 3 and 4 to 10 . The majority of the reduction in the $4 \mathrm{X}$ treatments could be attributed to the IMF4 treatment where fat percentage was 0.4 to 0.5 percentage units lower than $2 \mathrm{X}$ throughout the experiment. Because milk samples were obtained only at the first AM and PM milkings rather than all four milkings for the $4 \mathrm{X}$ groups, this may account for the lack of differences in FCM between the $2 \mathrm{X}$ and the $4 \mathrm{X}$ cows during the treatment period since milk fat content generally increases as a milking continues. However, this would not explain differences in milk fat during the posttreatment period.

Previously work by Wilde et al. (1995) proposed the hypothesis that increased MY as a result of IMF was due to the removal of a whey protein referred to as the feedback inhibitor of lactation (FIL). High concentrations of FIL have been associated with decreased milk secretion (Wilde et al., 1995) and more frequent removal of milk may rid the mammary gland of FIL therefore maintaining higher rates of milk secretion (Henderson and Peaker, 1984). Although this concept would explain MY responses during a period of IMF, it cannot explain the carryover effect of increased early lactation IMF on MY seen after IMF treatment ceased that was observed in the present study and others (Bar Peled et al., 1995; Henshaw et al., 2000). This would seem to preclude the possibility of an operative FIL mechanism posttreatment since milk removal in $2 \mathrm{X}$ cows was as frequent as $4 \mathrm{X}$ cows during this time and according to the FIL hypothesis, milk production should be similar between treatment groups.

In addition, though FIL has been shown to inhibit differentiation in vitro (Wilde et al., 1990), this effect of FIL on mammary cells is not consistent with carryover effects on MY since other studies have suggested the increase in MY until peak may be due to increased differentiation since there is no appreciable increase in mammary cells during early lactation (Capuco et al., 2001). Though mammary cell differentiation was not evaluated in this experiment, it is possible that IMF treatment may stimulate mammary cell differentiation.

To our knowledge, this is the first early lactation IMF study that also evaluated mammary growth effects in dairy cattle. Capuco et al. (2001) showed no net growth of mammary cells during early lactation in cows milked twice daily. However, small increases at the beginning of lactation may have been missed since the earliest mammary tissue sampling was $14 \mathrm{~d} \mathrm{PP}$ and it remained to be determined if IMF could induce mammary growth during early lactation in cows. Wilde et al. (1987) suggested that in goats, under a short, 2-wk IMF regimen, increased MY is due to an increase in mammary epithelial cell activity, whereas a longer IMF treatment period elicited an increase in mammary cell proliferation. In the current study, IMF1 treatment increased ${ }^{3} \mathrm{H}$-thymidine incorporation in the $\mathrm{d} 7$ mammary tissue. Though the Ki-67 localization results were not statistically significant, there was a quantitatively higher percentage of epithelial cells expressing the Ki-67 antigen in the d 7 tissue of IMF 1 cows and d 14 tissue of IMF4 cows. These results are consistent with our hypothesis that IMF treatment increases mammary cell proliferation, therefore providing a mechanism for increased MY and carryover effects.

Manipulating milking frequency not only alters the proliferative state of the mammary gland, but also might alter the apoptotic state. Studies by Li et al. 
(1999) showed differences in the apoptotic processes as evidenced by morphologic variation between $2 \mathrm{X} / \mathrm{un}$ milked glands and 3X/1X glands. This suggested a possible regulation of mammary apoptosis through local mechanisms sensitive to the frequency of milk removal (Li et al., 1999). In cattle, the proportion of apoptotic mammary cells during mid lactation has been estimated at $2.4 \%$ (Wilde et al., 1987) while other estimates of apoptotic rate are much lower, $0.07 \%$ during mid to late lactation and $0.27 \%$ during early lactation (Capuco et al., 2001). The apoptotic index estimated by Wilde et al. (1987) during mid lactation is similar to the apoptotic index seen in mammary epithelial cells of IMF4 cows at $\mathrm{d} 7$ of lactation of $2 \%$. The quantification of apoptotic mammary epithelial cells this early in lactation may be misleading since increased migration of leukocytes into the mammary gland and milk is characteristic of this lactation stage (Concha, 1986; Sordillo et al., 1997) and morphological changes that occur during the apoptotic process make it difficult to distinguish between an epithelial cell and an apoptotic leukocyte that has migrated into the epithelial compartment. Therefore, the incidence of apoptosis in mammary epithelial cells in early lactation may be lower than that estimated by TUNEL, with a higher rate of apoptosis may be due to migration of apoptotic leukocytes and increased tissue edema.

Implementing an IMF program might not only affect mammary cell turnover, but also endocrine profiles. Blood samples were collected approximately 1 to $2 \mathrm{~h}$ after milking to obtain basal concentrations of prolactin rather than milking-induced concentrations in the circulation. Milking frequency did not alter basal concentrations of PRL during or after the treatment period. However, increased milking frequency should have increased exposure of mammary epithelial cells to circulating prolactin due to milking-induced secretion of PRL at four milkings rather than two. Furthermore, Bar-Peled et al. (1995) observed more PRL released per milking when milking frequency was increased (6X versus 3X). Although basal concentrations of PRL were not altered by milking frequency, we cannot rule out PRL as a stimulator of mammary growth or differentiation during the treatment period.

Studies investigating bST effects on mammary growth appear contradictory. Whereas some studies (Capuco et al., 1989; Binelli et al., 1995) show no mammogenic effect of bST, other studies (Knight et al., 1992; Capuco et al., 2001) show a possible mammogenic affect when cattle are administered bST. Moreover, in cows that are administered bST under an IMF routine, Knight et al. (1992) suggested that increased mammary cell proliferation may contribute to the increase in MY. Work by Bar-Peled et al. (1995) showed higher endoge- nous bST levels in cows milked $6 \mathrm{X}$ as compared to $3 \mathrm{X}$, though these results were not significantly different, and may have reflected a change in energy status rather than an increase in MY (Bar Peled et al., 1995). Serum bST concentrations in the current study did not differ between IMF groups and $2 \mathrm{X}$ and decreased with time, suggesting that the possible proliferative effects on the mammary gland by IMF treatment were not mediated by systemic bST.

Insulin-like growth factor-1 has been shown to stimulate mammary DNA synthesis in vitro and is presumed to be the primary mediator of the galactopoietic action of bST in the ruminant (Prosser et al., 1990; Forsyth, 1996). Lower concentrations of IGF-1 in IMF cows argue against its involvement in eliciting a mammogenic response to IMF. Although we did not measure IGF-1 binding proteins, changes in IGF-1 binding proteins could have played an important role in regulating IGF1 levels both in the mammary gland and systemically. Furthermore, IGF-1 and IGF-1 binding proteins are also synthesized locally in the mammary gland and may act in a paracrine manner to regulate mammary growth (Hauser et al., 1990; McGrath et al., 1991).

\section{CONCLUSIONS}

Implementing an IMF routine increases MY during treatment and elicits a carryover effect on the remainder of lactation. Furthermore, increased milking frequency is equally efficacious when initiated immediately postpartum or after the milk withdrawal period (72 $\mathrm{h}$ PP). Milking frequency can be increased in a manner that minimizes additional labor by employing unequal milking intervals. Milk yield responses after an IMF routine may be the result of increased mammary cell proliferation.

\section{REFERENCES}

Bar-Peled, U., E. Maltz, I. Bruckental, Y. Folman, Y. Kali, H. Gacitua, and A. R. Lehren. 1995. Relationship between frequent milking or suckling in early lactation and milk production of high producing dairy cows. J. Dairy Sci. 78:2726-2736.

Binelli, M., M. K. Vanderkooi, L. T. Chapin, M. J. Vanderhaar, J. D. Turner, W. M. Mosely, and H. A. Tucker. 1995. Comparison of growth hormone-releasing factor and somatotropin: Body growth and lactation of primiparous cows. J. Dairy Sci. 78:2129-2139.

Capuco, A. V., J. E. Keys, and J. J. Smith. 1989. Somatotropin increases thyroxine- $5^{\prime}$-monoiodinase activity in lactating mammary tissue of the cow. J. Endocrinol. 121:205-211.

Capuco, A. V., and R. M. Akers. 1990. Thymidine incorporation by lactating mammary epithelium during compensatory mammary growth in beef cattle. J. Dairy Sci. 73:3094-3013.

Capuco, A. V. D. L. Wood, R. Baldwin, K. McLeod, and M. J. Paape. 2001. Mammary cell number, proliferation, and apoptosis during a bovine lactation: Relation to milk production and effect of bST. J. Dairy Sci. 84:2177-2187.

Concha, C. 1986. Cell types and their immunological functions in bovine mammary tissues and secretions-a review of the literature. Nord. Vet. Med. 38:257-272. 
DePeters, E. J., N. E. Smith, and J. Acredo-Rico. 1985. Three or two times daily milking of older cows and first lactation cows for entire lactations. J. Dairy Sci. 68:123-132.

Elsasser, T. H., T. S. Rumsey, and A. C. Hammond. 1998. Influence of diet on basal and growth hormone-stimulated plasma concentrations of IGF-1 in beef cattle. J. Anim. Sci. 67:128-141.

Erdman, R. A., and M. Varner. 1995. Fixed yield responses to increased milking frequency. J. Dairy Sci. 78:1199-1203.

Farr, V. C., K. Stelwagen, L. R. Cate, A. J. Molenaar, T. B. McFadden, and S. R. Davis. 1996. An improved method for the routine biopsy of bovine mammary tissue. J. Dairy Sci. 79:543-549.

Forsyth, I. A. 1995. The insulin-like growth factor and epidermal growth factor families in mammary cell growth in ruminants: Action and interaction with hormones. J. Dairy Sci. 79:10851096.

Hauser, S. D., M. F. McGrath, R. J. Collier, and G. G. Krivi. 1990. Cloning and in vivo expression of bovine growth hormone receptor mRNA. Mol. Cell. Endocrinol. 72:187-200.

Henderson, A. J., and M. Peaker. 1984. Feed-back control of milk secretion in the goat by a chemical in milk. J. Physiol. (London) 351:39-45

Hillerton, J. E., C. H. Knight, A. Turvey, S. D. Wheatly, and C. J. Wilde. 1990. Milk yield and mammary function in dairy cows milked four times daily. J. Dairy Res. 57:285-294.

Knight, C. J., J. E. Hillerton, M. A. Kerr, R. M. Teverson, A. Turvey, and C. J. Wilde. 1992. Separate and additive stimulation of bovine milk yield by the local and systemic galactopoietic stimuli of frequent milking and growth hormone. J. Dairy Res. 59:243-252.

Li, P., P. S. Rudland, D. G. Fernig, L. M. B. Finch, and C. J. Wilde. 1999. Modulation of mammary development and programmed cell death by the frequency of milk removal in lactating goats. J. Physiol. 519:885-900.

Lush, J. L., and R. R. Shrode. 1953. Changes in milk production with age and milking frequency. J. Dairy Sci. 33:338-357.
McGrath, M. F., R. J. Collier, D. R. Clemmons, W. H. Busby, C. A. Sweeny, and G. G. Krivi. 1991. The direct in vitro effect of insulinlike growth factors (IGFs) on normal bovine mammary cell proliferation and production of IGF binding proteins. Endocrinol. 129:671-678.

Miller, A. R. E., E. P. Stanisiewski, R. A. Erdman, L. W. Douglass, and G. E. Dahl. 1999. Effects of long daily photoperiod and bovine somatotropin $\left(\right.$ Trobest $^{\circledR}$ ) on milk yield in cattle. J. Dairy Sci. 82:1716-1722.

Pearson, R. E., L. A. Fulton, P. D. Thompson, and J. W. Smith. 1979. Three times a day milking during the first half of lactation. J. Dairy Sci. 62:1941-1950.

Poole, D. A. 1982. The effects of milking cows three times daily. Anim. Prod. 34:197-201.

Prosser, C. G., I. R. Fleet, A. N. Corps, E. R. Froesch, R. B. Heap. 1990. Increase in milk secretion and mammary blood flow by intra-arterial infusion of insulin-like growth factor-I into the mammary gland of the goat. J. Endocrinol. 126:437-443.

Sanders, A. H. 2000. The effects of six times a day milking in early lactation on milk yield, milk composition, body condition, and reproduction. M.S. Thesis, Univ. Maryland, College Park.

Sordillo, L. M., K. Shafer-Weaver, and D. DeRosa. 1997. Immunobiology of the mammary gland. J. Dairy Sci. 80:1851-1865.

Tucker, H. A. 1966. Regulation of mammary nucleic acid content by various suckling intensities. Am. J. Physiol. 210:1209-1223.

Tucker, H. A. 1981. Physiological control of mammary growth, lactogenesis and lactation. J. Dairy Sci. 64:1403-1421.

Wilde, C. J., A. J. Henderson, C. H. Knight, D. R. Blatchford, A Faulkner, and R. G. Vernon. 1987. Effects of long-term thricedaily milking on mammary enzyme activity, cell population and milk yield in the goat. J. Anim. Sci. 64:533-539.

Wilde, C. J., C. V. P. Addey, L. M. Boddy, and M. Peaker. 1995. Autocrine regulation of milk secretion by a protein in milk. Biochem. J. 305:51-58. 